\title{
Screen Image Of Muslim Women In The Popular Post-9/11 Films On War On Terror
}

\author{
Muhammad Shaban Rafi \\ Department of English Language \& Literature \\ University of Management and Technology, Lahore
}

\begin{abstract}
The purpose of this study is to deconstruct the screen image of Muslim women in the post- 9/11films on American war on terror. The data was drawn from four popular films (i.e., American Sniper-2014, Jarhead 2: Field of Fire-2014, Zero Dark Thirty2012 and Body of Lies-2008) depicting the post 9/11American war on terror in the Muslim countries such as Afghanistan, Iraq, Jordan, Pakistan, Oman, and Syria (henceforth 'the Muslim society'). The study built its theoretical foundation by drawing from discourse analysis, critical theory and deconstruction. It is observed that social reality projected in the selected films hinges on different discursive practices manifested through linguistic styles, actions, objects, settings, graphic illustrations and sound tracks. In addition to the identification of the Muslim women in the oppressive discourses, the study unlocks some hidden meanings by acknowledging their professional contributions in the social institutions. The Western Caucasian women, usually empowered to exercise their rights, present a huge contrast to the Muslim women who are dangerously marginalized mostly if not always by the abrogation of rights. The study suggests that the representation of educated and professional women along with those who are oppressed can be a powerful strategy to resist misogynist discourse prevailing in the Muslim society.
\end{abstract}

Keywords: Muslim Woman, Oppressive Discourses, New Women, War on Terror, Post-9/11 Films.

\section{تلخيص}

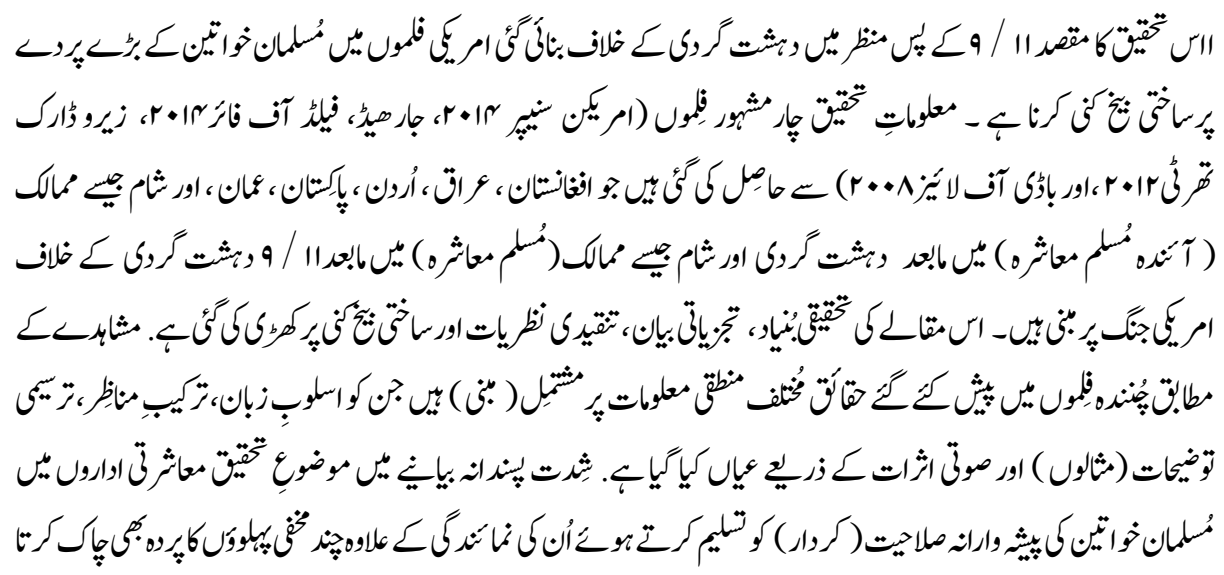




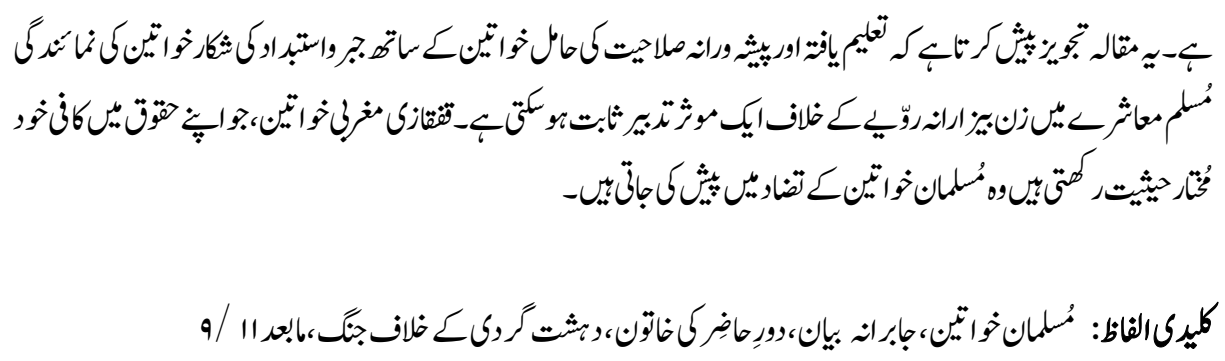

\section{Introduction}

There is a plethora of literature available on feminism (Woolf, 1929; De Beauvoir, 1949; Millett, 1970; Foucault, 1976; Spivak; 1996; Clement and Kristeva, 2001; Butler, 2010) that allows me to focus on the missing strand within this available research and bring to the fore limited conversations on the representation of Muslim women in the films on American war on terror in the post 9/11 (henceforth 'war on terror'). Shaheen (2000, p.37) argues that a few scholars have documented and discussed media images of Muslim women. The representation of the screen image of Muslim women though narrates real account of events seems in contradiction with millions of Muslim women who are spending a successful life in various professions. The kind of work I have outlined seeks to destabilize the established knowledge about the Muslim women especially in the context of popular culture and film.

I aim to investigate not only the image of oppressed Muslim women but also to bring to surface the successful struggles of educated and professional women (henceforth 'new women') who are observed to resisting the misogynist discourse. The study is an affirmative deconstruction (Derrida's phrase) of strategies that filmmakers have been applying to persuade the oppressed Muslim women to enact power. To begin with this investigation, it is very important for us to understand the ethno-cultural landscape prevailing in the Muslim countries in case. Generally speaking, almost two third of the Muslim population is from the rural/remote areas where women work in fields, farms and homes. For many reasons they are restricted by certain norms usually imposed by men to advance economically (e.g., Kasturi, 1996). Mostly if not always, they have to look towards male members of their community for decision making. They are forced to adhere to traditional Islamic barriers, such as limits on mixed-sex interaction, and communication with their male counterparts. They have to wear culturally approved dresses which can cover their bodies. They are bound to live under combined family systems where elders play a dominant role. Further, they are silenced through arbitrary cultural norms and psychological pressures that label them as the 'honour' of the family and their immediate guardian (usually husband, father and brother) as the de facto custodian of that 'honour'. Thus, because of the cultural and psychological demands, the male members of community are forced to limit the social practices and mobility of their female dependants. 
The rural women are squarely burdened by religion and patriarchy as has been rightly depicted by Barmak (2003) in his drama film 'Osama'. For instance, the Islamic Institutions (mainly funded by State) such as Council of Islamic Ideology (CII) of Pakistan allows the husband to beat his wife if needed and prohibits mixing of gender in schools, hospitals and offices (Khan, 2016). The Council also believes that a woman smiling is against the laws of their self-proclaimed Sharia. Such decisions confine women who are almost 50 percent of the total population in Pakistan to a very limited social and professional space. Salami and Ghajarieh (2016) conclude that society and state are influenced by patriarchal values. Some people believe that the anti-women position of the CII promotes violence against women and has contributed to an increase in crimes against the gender (Riazul-Haq, 2016). Jamal (2010, pp. 120-139) highlights that the dominant discourses and ideologies surrounding the Muslim women (and their bodies) are further propagated within the contexts of their families, community, and nation. Such discursive practice gives an impression that this is a men's world and God belongs to them only. From a Lacanian perspective woman does not even exist (Cited in Caputi, 2013:2).

From the foregoing it appears that rural communities have internalized the dominant misogynistic discourse (Ahmad, 2010, p. 8) that is prevalent in their daily life. They feel that men have the right to be in control of their lives and bodies. Tyson (2006, p. 120) argues that man's dominance has secured an ideological climate of compliance from women. Any resistance to men's biological, psychological and economic discriminative attitude is met with dire consequences for women e.g., psychological or/and physical torture, divorce, acid attacks and honor killing - usually labeled as Karo Kari and Siyah Kari (Patel and Gadit, 2008; Lari, 2011; Bhanbhro et al. 2013). With honor killing so rampant women are denied access to education (See e.g., Khoja-Moolji, 2015) maybe to keep them subservient of inhuman rituals. Lazar and Kramarae (2011:217-240) note that women are doubly oppressed and silenced through gender and poverty. Pratt (2016) says that social norms, legal restrictions and gender-based violence prevent women from accessing economic opportunities. Even their economic contribution to society through engaging in different kinds of work is kept secret as explicated by Marx as the only example of zero-work (c.f., Rouse, 2004). They are rarely treated as equal members of society and often find themselves relegated to subversive discourses.

The experience of women varies in the patriarchal discourses mainly due to regional and cultural differences as envisaged by Tyson $(2006,2009,2015)$ who argues that patriarchy does not work in the same way in all the countries even within the same country. Foucault (1976:95) has rightly stated that where there is power there is resistance. Unlike the rural women, those who are from the urban areas are mostly educated and formally employed, developments which are shifting the emphasis on the characters of power (c.f., Kasturi, 1996). Women are contributing in all the social institutions such as family, 
education, media, politics, army and judiciary. They are independent in their decision making and follow modern trends in clothing, make-up, cuisine, cell phone and so on. The decisions of Islamic councils hardly affect their everyday life. They enact as subjects who contest power (Mills, 2005). It may be unfair to compare them with the women in rural communities. There is a common observation that women who are either less educated or uneducated remain dependent on male members (Khoja-Moolji, 2015). They are subject to oppression in most of the discourses. We find resistance to these discourses in Islam by 'new women'. Undoubtedly, media is playing a crucial role to support their resistance against the misogynist discourses.

Hollywood has produced numerous award winning films and documentaries on the social life of Muslim women. Tyson (2006:4) says that the screen images of Muslim women convey ideas and feelings regarding how the story-line illustrates a theme or mirrors the prevalent social discourse or communicates the director's viewpoint. They are often portrayed as being suppressed, controlled, abused and victimized by the Muslim society. These patterns have been regurgitating even in the films on post 9/11 American war on terror. The films on terror appear to be creating the discourse of resistance against the misogynist forces by drawing a parallel to Western matriarchal ideology. The Muslim women are shown being controlled by the self fabricated Islamic ideology often associated with Sharia Law (religious system to govern the members of Islamic faith). For example; in Jarhead 2: Field of Fire (henceforth 'Jarhead 2') while punishing Aanush, Mullah Nafees says, "We need to return to our way of life - the Sharia way of life. And for this you will die". The present study seeks to uncover some deep truth in practices. Said (1978) argues that it is very important for the post-colonial thinkers to see truth in the constructed factual accounts of colonized countries by the colonial powers (as cited in Mills, 2005:75).

\section{Theoretical Frameworks}

The present study aims to reveal the oppressive discourses as constituted in intellectual practices of filmmakers (c.f., Spivak, 1996:69). We can achieve this while investigating the screen image of Muslim women through text and dialogue. Van Dijk (2011:3) notes that language users engaged in dialogue accomplish social acts of many kinds by coordinating their action as meaningful in a discourse. He further explains that discourse on the one hand is an important condition for social inequality and on the other hand a prominent tool for resistance. Howarth (2000:4) asserts that the task of discourse analysis is to expose the way in which language and meaning are used by the powerful to deceive and oppress the dominated. Discourse, women and patriarchy are inextricably linked and established in the work of Althusser (1971), Gramsci (1971), Foucault (1972), Lakoff (1973), Thorne and Henley (1975), Habermas (1987), Wodak (1997), Sunderland (2004), Laclau (2007) and Strauss and Feiz (2014). It is hard to delink women and hegemonic practices in the Muslim society - both of them are quite crucially shaped by discourse. 
We will look into various discursive practices with particular ideological investments in dominance in the screen image of the Muslim women. Through the close analysis of language texts and multisemiotic aspects such as visual images and sound effects, we will explore how misogynist discourses operate in the Muslim society in general. While applying discourse theory on empirical research objects I draw upon Critical Theory and Deconstruction in order to counter the charge that discourse analysts are no more than armchair theorizers. Howarth (2000:134) explains that there is no one method of conducting discourse analysis, but rather different styles of research compatible with its social ontology. Thus, we are concerned with how, under what conditions, and for what reasons, misogynist discourses are constructed, contested and changed in the films on war on terror.

These discourses do form a backdrop against which our use of Critical Theory (CT) positions itself, for we are in agreement with a worldview that privileges the voice of the marginalized. Tyson (2006, p. 5) explains that CT often examines the ways in which women are psychologically and socioeconomically oppressed. It provides an analytical lens, drawing especially on the work of Jacques Derrida, to think logically, creatively, and with a good deal of insight into valued voice of the sufferers (Caputi, 2013:1-30). Derrida's concepts such as the instituted trace or trace structure, différance and iterability form the basis for deconstructive strategy. He argues (1982:307-330) that trace is infinitely repeatable and alterable in different discourses, and that meaning is a product of différence (as cited in Howarth, 2000:41). The representation of Muslim women in comparison with Western Caucasian women (henceforth 'the Western women') contains traces of binary oppositions (as illustrated in figure 2) surrounding their everyday life unravel oppressive discourses that the Muslim women are experiencing. Moreover, differrence mediates the way a meaning is produced by interplay of traces and deferment of certain practices. Caputi (2013:xvi) argues that the Derridean concept of difference is useful here as it highlights the fluid, contingent nature of truth claims, undermining the authority of any given position by drawing attention to its relationship with what has been silenced and marginalized. However, iterability is captured through repeatability and alterability of images and symbols used in different films. For indeed, regardless of my cultural affiliations and intellectual traditions I have carefully examined the ways women are silenced in the Muslim society.

CT is useful especially at the time when the USA is fighting a war on terror in the Muslim world and its relationship with the Muslim communities weighs more heavily on everyday life than ever before. CT helps answer the realities (which have been screened by various filmmakers) of the ever increasingly penetrated Muslim world. The theoretical conceptions laid down by $\mathrm{CT}$ forces me to contemplate the relationship between misogynist discourses and extremism at least in the remote regions (mostly not administered by the Islamic States in case). This relationship has been very well depicted 
by Mansoor (2007) in his film "Khuda Kay Liye". The study speculates that there is a kind of link between oppressive discourses and extremist practices. The films on war on terror mirror this link as well. Shaheen (2001) notes that films are a product of human experience and therefore they reflect human desire, conflict and potential. I interpreted films in the broader sense of the term to include all signifying systems, including dialogues, objects, actions and settings that give access to discursive practices constituted in the Muslim communities. Unlike the structuralists (Sassure, 1974; Levi-Strauss, 1977 and those cited therein) who deem meaning making is central to 'structure', the present study, however, de-centers meaning and assumes 'signifier' as the ultimate carrier of meaning, which signifies personal experiences (Derrida, 1976).

\section{Data Collection}

Hollywood had been quite popular and successful in presenting the post-war shared beliefs and experiences of American soldiers from various fronts e.g., Vietnam, USSR (now Russia) and the Middle East until 9/11 happened. The event had a great impact on the USA in particular and on the rest of the world in general. Filmmakers were no exceptions. They began to film on the experiences shared/leaked by Pentagon or American soldiers. The primary focus of these films is on war on terror in the Muslim countries. Among their experiences is a representation of women in these countries. The study investigates how the Muslims women are identified within the Muslim society and whether they can be compared with the Western women who remain in the hearts and minds of American soldiers and are assigned various roles. The data was drawn from four popular films (American Sniper-2014, Jarhead 2-2014, Zero Dark Thirty-2012 and Body of Lies-2008) on post-9/11 war on terror in the Muslim countries (such as Afghanistan, Iraq, Jordan, Pakistan, Oman, and Syria). A film acclaimed on the box office was considered to be popular. It tends to draw attention and interest of most of the viewers who give it rating. It is considered that a popular film is supported by a well thought out script. One of the reasons of the popularity of these films on the box office is that they showcase setting and background of the countries which have been in the news for their troubled history since ages.

\section{Nature of Data}

As it is shown in figure 1 the data was based on dialogues, acts, objects and settings. The dialogues were mainly in the English language and some in the regional dialects e.g., Arabic, Persian and Urdu. The tone of dialogues can be classified on formal and informal ends of the continuum. The acts were seemingly labeling characters who could be identified through their appearance and language easily. The objects used further symbolize them who they are. The settings in the films portrayed characters involved in their daily chores. The theme that emerges from these aspects i.e., dialogues, acts, objects and settings provide insight into hegemonic practices in the Muslim society. 


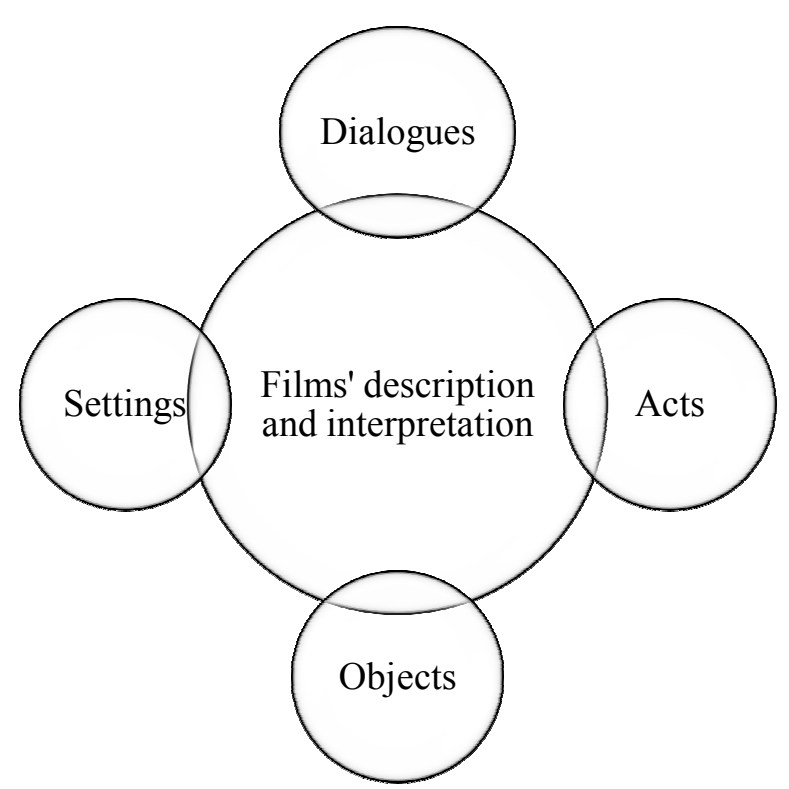

Figure 1 Faceted classification of the data

\section{Data Analysis}

The theoretical frameworks elaborated in the section 2 lay the procedure for analysis. The analysis begins with a process of familiarization and subsequent labeling and sorting in commonly emerging discursive practices and their realization in language texts and multisemiotic texts. As elaborated in figure 1, the analysis procedure covers description and interpretation of dialogues, acts, objects and settings. The focus of analysis was on the selected texts, most rightly the representative texts, and their link with power relations and ideological processing of discourses. Fairclough (2010:78) rightly declares that discursive practices are the processes of text production, distribution and consumption. This has been affirmed by Siddiqui (2014) who deems the text a useful lens to mirror personal and social relations. Fairclough (1998) explains that a range of properties of texts is regarded as potentially ideological including features of vocabulary, grammar, style, presuppositions, implicatures and politeness conventions. In addition to the analysis of language texts, the study interpreted certain binary oppositions (e.g., oppressed/liberal, conservative/modern, dependent/independent and so on) and semiotics (e.g., object, gaze, and sound effects and so on) for patterns of meaning.

At the first stage, I analyzed language texts and multisemiotic characteristics of the selected text. The linguistic characteristics include investigation of forms and subsequently their meanings in the context. I tried to reduce the inherent complexity of what films cover by adopting, if not all possible aspects, but dialogues, acts, objects and settings ascribed in the oppressive discourses. The first stage of analysis was followed by 
the second stage in which I interpreted the texts to explore the kinds of functions they serve by seeing how they are embedded within the social structures (e.g., oppressive vs. liberal discourses). The study dispenses what underpin such practices and anticipates what their implications are. Yanow (2014:5-23) maintains that meaning-making is the ultimate focus of interpretative approach. The approach helped in analyzing obstacles and potential means to surpass the oppressive discourses. I may not rule out the influence of my cultural experiences, beliefs and ideologies in the interpretation of the text.

\section{Results and Discussion Dialogues}

As shown in figure 2, there is a huge contrast between the Muslim women and their Western counterparts. Such a contrast also exists between the Muslim and the Western society. The Muslim women are largely portrayed as oppressed, pre-modern, dependent, and with many-children in a patriarchal, conservative, radical, and backward society. In contrast to this, the Western women are shown liberal, modern, independent, and with two-children in a democratic, civilized and developed society.

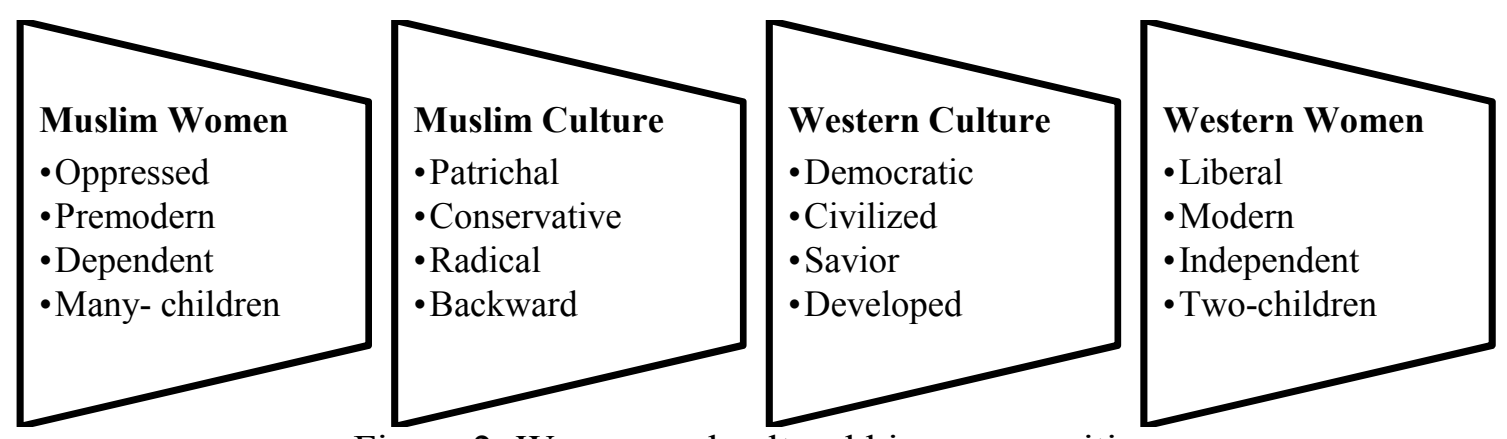

Figure 2: Women and cultural binary oppositions

The voice of the Muslim women has been occluded which seems to blur the reality. In American Sniper, they were kept silent. However, they were trying to communicate both resistance and submission through body language (e.g., gaze and facial expression). When Mustafa's (the Iraqi sniper) was leaving home to kill American soldiers, his wife could not say anything but she reacted through a 'gaze', which was perhaps anticipating terrible consequences. In the Body of Lies the gaze of Aisha when she was looking at Ferris being taken by Marwan demonstrates her helplessness. Keeping the Muslim women silent in the films seems quite a successful strategy to reveal their oppressed state of existence. In another setting while responding to Ferris who was suspecting Asia was tortured, Honi Pasha said, "she is a nurse. She gives blood every month". The dialogue is reminiscent of inhumane treatment of women; a deep rooted issue in the Muslim society. As shown in Image 1, they remain either silent or wailing or pleading. It was shown that silencing discourses were achieved through coercion and hegemony. 


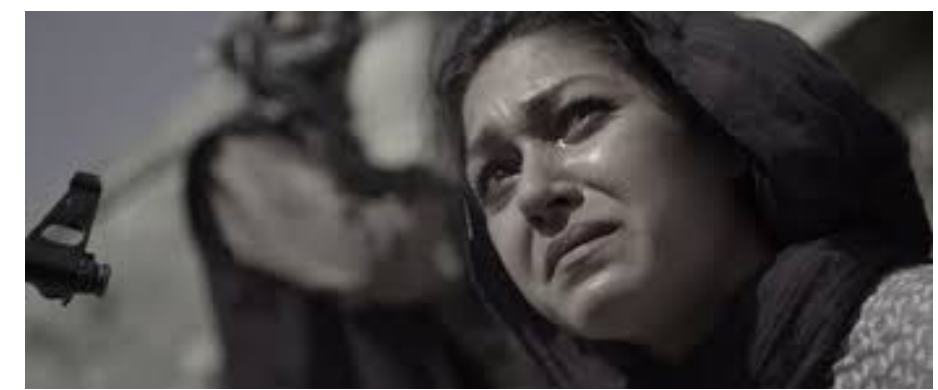

Image 1: Aanush cries for help when seized by Talibans in Jarhead 2

As mentioned above, the Muslim women characters were not allocated dialogues in most of the cases. However, in the contexts in which they are engaged in talking, they seem to be representing new women under the Western influence or they are shown as living in the Western society. In Jarhead 2, Aanush, who graduated from the University of Cambridge, had been fighting for the rights of women in Afghanistan. Even though she was being tortured physically, her dialogues [1] with Mullah Nafees (Taliban leader) reflected how bold she was. The dialogue with Aanush left the Taliban leader speechless. When he could not respond he simply seized her face to show his aggression that reflects how women's voice is usurped in patriarchal societies. This also reveals that education empowers women to speak for their rights without any fear.

Talban: Afghanistan does not need the Western influence and it has to come back to its own way of life which is the Sharia way of life.

Aanush: What you're preaching is nothing more than a perversion.

Talban: You picked a wrong fight and for this you will die.

Aanush: We will all die, some better than others. You may be able to kill me but you will never be able to kill an idea. In my place there will rise a thousand more. My paradise awaits me. But for you only hell awaits."

Unlike the Muslim women who were portrayed with restricted social and family life, the Western women are depicted as performing a very crucial role in their family. Teya's argument with Kyle at various occasions gives the impression that she has the freedom of speech denied to the Muslim women characters. She denounces him for not finding time for her when he is deployed on an important mission inside Iraq. In a phone call to him she complains, "I am sitting here by myself. Literally assembling baby cribs and you can't even talk to me". In another instance, her speech shows how American war on terror is disturbing the social and psychological health of her husband. She points out to Kyle, "Even when you are here you are not here. I see you, feel you but you are not here. If you think this war isn't changing you, you are wrong". In order to reduce his stress, she wants him to share his experiences. The films on terror do not set such precedence for the Muslim women to derive from in their family life. 
There is no one but a Western woman (Maya) who helped hunt down Osama Bin Laden. Her dialogues [2] with the station chief of CIA in Pakistan depict how brave she is. She is given very eloquent and powerful dialogues. Her character is a huge contrast with Aisha who is allocated the role of a working woman in Body of Lies. Unlike other Muslim women characters, Maya is resisting and challenging her male colleagues' hegemony. Nothing could stop her to achieve her goal.

Maya: I really need to talk to you about briefing up surveillance operation.

Chief: We don't have a surveillance operation... someone just tried to blow up Times Square and you are talking to me about some facilitator, some detainee seven years ago said might have been working with Al Qaida.

Maya: He is the key to Bin Laden.

Chief: I don't fucking care about Bin Laden. I care about the next attack. You are gonna start working on the American Al Qaida cells. Protect the homeland.

Maya: Bin Laden is the one who keeps on telling them (terrorists) to attack the home land. If it wasn't for him, Al Qaida wouldn't still be focused on overseas targets. If you really wanna protect the homeland, you need to get Bin Laden.

Chief: This guy never met Bin Laden. These guys are... working on the internet. No one has even talked to Bin Laden for 4 years. He is out of the game. He may be dead. He might as well be fucking dead but you know what you are doing? You are chasing the ghost. All the fucking network goes around you.

Maya: You just want me to nail some low level...Y You can check that box in your resume that says while you are in Pakistan you got real terrorists but the truth is you don't understand Pakistan and you don't know Al Qaida. Either give me the team I need to follow this lead or the other thing you are gonna have under your resume is being the first station chief to be called before congressional committee for subverting the efforts to capture or kill Bin Laden.

Contrastively, the Muslim women are shown largely submissive nonentities, dependent, and culturally conservative. They are restricted to choose even their life partners. For this, they have to look towards their elders who hold power to decide the course of their life. In body of lies, when Ferris shows interest in Aisha, she advises him in quite fractured English, "if you are going to insist on coming here to see me which is what you are doing my sister is going to want to meet you...My sister looks after me in matters that are non-medical". Perhaps she was obliged to speak garbled English. Unlike Aisha, Teya in American Sniper is portrayed as a self-made and independent woman who meets Kyle in a bar, falls in love and decides to marry him. The Western women are dominating and independent in their dialogues. Moreover, the acts women were performing in the films on terror further explain about them.

\section{Acts}

The acts assigned to the Muslim women are mainly of wife and mother. They are found either with children or serving their husbands. In American Sniper, when the American soldiers raided a house the camera captures a woman and her children. Despite the 
presence of her husband, she helps the children to calm down and serves dinner to the soldiers. Later she is shown collecting the cutlery for cleaning. In the same film Mustafa the Iraqi sniper's wife is trying to make her baby sleep whereas her husband is preparing to kill the American soldiers. In Body of Lies, Basam's wife, as shown in image 2 is preparing food for her child even though she is pregnant. Similarly, in this film, Pasha's wife Suda is also shown serving food to her family. In another act she is called by Pasha to tie up his sleeves button. In the films on terror we can observe that the Muslim women are mainly involved in either nonpaid jobs or low paid jobs or self-employed jobs and home chores. These acts depict in general abrogation of their basic rights (e.g., speech, education and employment) in the Muslim countries the selected films are based on.

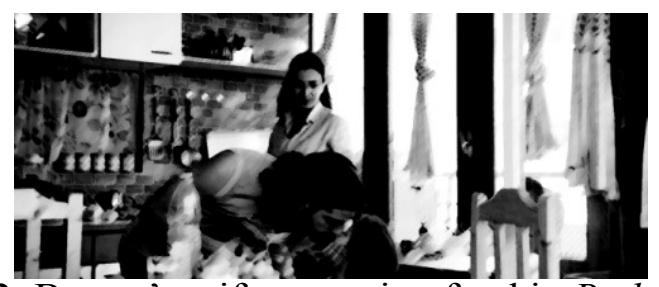

Image 2: Basam's wife preparing food in Body of Lies

Muslim women are further pushed into terrorist activities. To associate them with Islam, such acts are combined with the recitation of Azan (call for prayer), rattling sound of tanks and marching of soldiers. This finding can be generalized over most of the films on war on terror. At the onset of American Sniper, while we hear Azan in the background along with the movement of American soldiers in a filthy and devastated neighbourhood of Iraq, a woman in Burqa as shown in image 3 appears through a door along with a child to attack them with hand grenade. She is being monitored by a man standing on the roof with a mobile phone. The act of terrorism by her is further dramatized through various semiotic devices and sound tracks. Even women wearing the traditional Muslim Hijab/Burqa are associated with terrorist activities. Perhaps, such acts refer to Islam as a bizarre ideology.

In contrast to the Muslim women, the Western women are portrayed as caring, brave, saviors, confident and hardworking. In American Sniper when Teya knows about Kyle's hypertension, she argues with him to take proper rest and medication. In Jarhead 2, Annie, a marine solider, fights very hard along with other soldiers against Talibans to bring Aanush to the base camp. In Zero Dark Thirty, Maya proves to be very intelligent and brave while hunting down Osma Bin Laden with his associates in Pakistan and elsewhere. In Body of Lies, the Western women assist their male colleagues to pin down terrorists from the satellite station. It seems that these films draw a fine line between the Muslim and the Western women who are further distinguished through a set of fixed objects.

\section{Objects}

The Muslim women are shown suppressed through semiotic dimensions of social practice. They are usually identified with Hijab/Burqa/Niaab to symbolize their oppression in Islam. In Jarhead 2, Aanush veils herself especially while taking refuge from her own countrymen. It shows that the Muslim women are married to men who possess and 
oppress them. In American Sniper they even wear Burqa in the presence of their immediate family at home, which shows that they live under the influence of an oppressive discourse that makes it obligatory for them to cover themselves. In Zero Dark Thirty, even Maya was observing Hijab while interacting with the Muslim males. Though Parda is a symbol of religion and culture, it is linked with terrorism. Certain events in the films are interpolated to highlight Hijab/Burqa/Niqab wearing women as associates of terrorists. In American Sniper a woman who informs Mustafa (the Iraqi Sniper) about the presence of American soldiers is in Burqa. In Zero Dark Thirty, a male terrorist gets himself discharged by wearing Burqa at the compound of a mosque in Rawalpindi, Pakistan. This perpetuates a negative image about Burqa that can be used in terrorist activities and mosque being a safe haven for terrorists. Shaheen (2000) also argues that more recently image-makers are offering caricatures of Muslim women covered in black from head to toe to depict them as unattractive and enslaved beings - solely attending men. The uses of certain religious and cultural tropes are exploited in the films to prove Islam as a fundamental ideology.

Muslim women are shown as captives in their homes. They are kept busy with household objects e.g., utensils and eatables as depicted through image 2. In case they are performing a role outside the four walls of their homes they are carrying explosives, gun, hand grenade and bags filled with eatables. As depicted in image 3, a woman covered in burqa is spotted by Kyle while passing on an explosive object to a child to blow up American soldiers in the name of Allah. The finding is in parallel with Shaheen (2000:26) who reveals that the Muslim women surface as gun totters, or as bumbling subservients, or as belly dancers in Hollywood films on Muslim Arabs. Such objects seem to link them with terrorists. This gives the impression that they are too helpless to resist even the criminal activities. The purpose to show them along with these objects is to portray how submissive they are. They are dotted with eatables, goats, camels, and chicken. Eventually, they are denigrated as dehumanized caricatures.

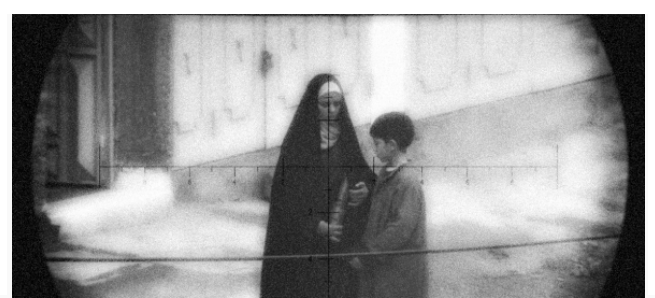

Image 3: Muslim woman passing hand grenade to her son in American Sniper

On the other hand, we are shown the Western women with a completely different set of objects e.g., laptop/computer, paper \& pencil and smart phones. They wear modern attire or uniform. In Zero Dark Thirty, Maya works on a computer and takes notes. None but she drives alone in the streets of Islamabad. In Body of Lies, the Western women work at the satellite station to assist their colleagues in hunting down terrorists. In Jarhead 2, Annie, as shown in image 4, is the USA marine who assists in the supply mission. She is 
portrayed as a very strong soldier who fights hard to save Aanush from the clutches of Talibans. Though she has a daughter who is waiting for her return she is fighting fearlessly to terminate the bad guys. These images reflect the Western women diametrically opposite to the Muslim women. The portrayal of these objects draws a fine line between the West and the Muslim world in general. Even the settings they are shown in clearly explain the Muslim women.

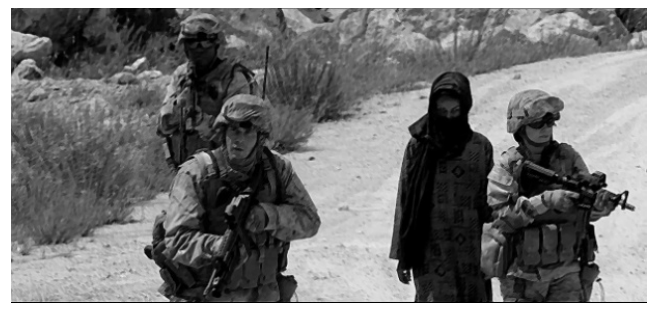

Image 4: Annie with her colleagues rescuing Aanush in Jarhead 2

\section{Settings}

As it is evident in image 5, the Muslim women are mostly confined to a messed up setting of a home or a market. In the films on war on terror, women are shown doing green grocery from a donkey cart, waiting for their turn in the health center, or cooking food for the family. Aisha in Body of Lies is found in a number of contexts i.e., clinic, home, neighborhood and a market which showcase poor living conditions. Aanush in Jarhead 2 is represented through devastated and disorganized settings while she speaks for the rights of women. In Zero Dark Thirty women are shown either at home or at market settings. The compound of Osma Bi Laden's house is a perfect example of how women are limited to the four walls of the house. Such images mirror the oppressive discourses which enforce the ideologies of dominance, inequality, control and hegemony.

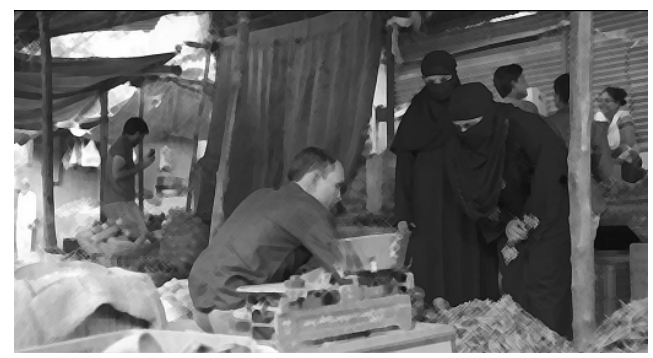

Image 5: Muslim women at the market setting in Zero Dark Thirty

In contrast to the settings in which the Muslim women are portrayed, the Western women appear in peaceful, clam and serene settings in these films. Image 6 from American Sniper verifies this finding. Moreover, this image picturizes a spectacular setting of the USA. On the contrary, we do not witness such a setting in the Muslim countries in case. 
They are mainly depicted with war torn settings. The background melody and chirping of birds illustrate how happy the Western women are. All the films show the Western settings as clean, organized and mesmeric. Even the setting of the Western graveyard is better than the Muslim countries in subject. Such images reflect that the Western women are far better and prosperous than their Muslim counterparts who are spending abysmal life in the war torn society.

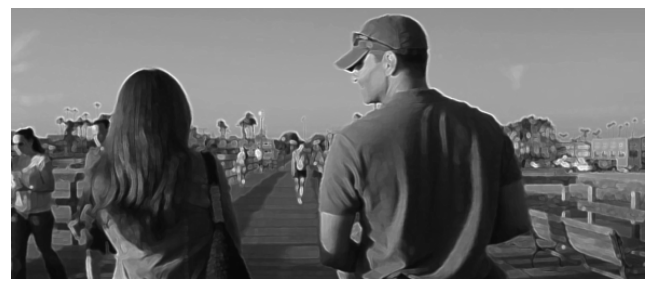

Image 6: Teya with Kyle at beach in American Sniper

The forgoing discussion implies that Hollywood is trying to liberate the Muslim women by stimulating the feeling that their counterparts are more liberal, independent, civilized and disciplined. For example, Kyle's wife in American Sniper, Maya in Zero Dark Thirty, Aanush in Jar Head 2 are shown role models for them. They are not just sex partners who can be denied freedom of speech and choice. They are shown as standing shoulder to shoulder with men while doing home chores, looking after children, and going for shopping along with fulfilling the responsibilities of professional life. Such images inject a powerful feeling in the Muslim women to raise their voice for sexual liberation. The emancipation of Muslim women through the Western ideology though a popular move is readily accepted by American viewers and tends to stimulate reaction and xenophobia in them.

The viewers who have never been to Afghanistan, Iraq, Jordan, Pakistan, Oman, and Syria find such films as one of the best sources of information. The common observation of an average young American is that the Muslim women are extremely suppressed. They always clamor for their rights. They get the right to education when Malala Yousafzai (Nobel Prize Laureate, 2014) or Sharmeen Obaid-Chinoy (Oscar award winning for best short subject documentary 2012 and 2016) struggled for them. It seems very difficult for common viewers to understand Islam and Muslims when their source of information is only confined to films. Alwan (2012:15) argues that this is especially problematic because films are situated as a reference point for audience who realistically have limited exposure to Islam. Russell (1988:114) explains when an actor says something that usually confers falsity as a truth, nobody says he/she is lying. McKee (1997:375) in the same vein says that audiences relate to characters as they are real. Thus, the films on terror as the only source of information about the status of women in a Muslim society can be very misleading. 
The representation of Muslim women in the Hollywood films is unidirectional and simplistic which cannot be generalized over the entire population at least in the case of films on war on terror. Haeri (2010:278) argues that women in the Muslim societies are depicted is such a way that their life styles seem remote and far flung from the western women. Similarly, Ahmed (2010:1) states that there is asymmetrical presentation of the Muslim women in the international feminist literature as living inactive, oppressed life under the strict control of religion and misogynistic environment. Saigol (2011) explores the traditional concept of power relation between men and women which has undergone radical transformation. The representation of lop-sided women characters in the Muslim society is quite a popular narrative exploited by film directors and readily accepted by the audience. The blatant gender discrimination is not as widespread in the Muslim society as it is portrayed in the Western media. There is no denying the fact what is presented on the screen is based on real events but they are in sharp contrast with different cultures within the same society (Tyson, 2006, 2009, 2015).

Critiques (such as; Alwan, 2012; Wilkins, 2009; Semmerling, 2006; Shaheen, 2001, Said, 1978, and many referred therein) point out that Hollywood shows restraint to present a comprehensive picture of Islam. This study suggests that the emancipation of Muslim women through the western narrative remains limited unless it is backed up by true Islamic ideology that gives women rights similar to men in a just manner. This view is supported by Alwan (2012) who declares that this is an essential first step for filmmakers towards an accurate perspective of Islam that eventually reconnects viewers to a reality beyond politics, hype and fear. Shaheen (2000) also criticizes that most image makers do not have the religious, cultural or language background to understand Islam. There is a reason to believe that they may not be able to go beyond much established caricatures of Muslim women, which can perpetuate a widespread hatred and reaction among viewers. A growing strain of intolerance especially among young Muslims who are occasionally reported exercising extreme practices is in reaction to how they are portrayed/treated (e.g., The Guardian, 2014). Benali (2015:6) argues that "the lure of extremism can be very powerful when you grow up in a world where media seems to mock and insult your culture".

\section{Conclusions}

The study helps to learn something important about the oppressive discourses in the Muslim Society. The Muslim women are seen as slaves, victims, helpless, ignorant and duped caricatures in the public and private spheres. Themes such as abrogation of women rights, suppression, lack of democracy, education and corruption in Afghanistan, Iraq, Jordan, Pakistan, Oman, and Syria are being recycled in the films on war on terror demand attention. There is every reason to believe that the images which are readily acceptable are usually repeated by the filmmakers. The strategy, though popular and 
successful, obscures the capacity of viewers to formulate a genuine perspective about educated and professional Muslim women who live mostly in the urbanized settings and are capable of resisting and rejecting oppressive ideologies suggest no ideological mechanisms instrumental for achieving social cohesion. No doubt, the representation of 'new woman' like Teya in American Sniper, Aanush in Jarhead 2 and Maya in Zero Dark Thirty along with those who are oppressed is a powerful strategy to resist dominant discourses. The strategy that apparently converges the Western centrism will achieve limited results unless it is supported by true Islamic ideology that simply equates the men and women in a just manner and allows mixed sex interaction without the self fabricated limitation of Parda. The strategy is squarely helpful in staunching extremist practices rooted in the patriarchal mind sets originally located mostly if not altogether in the rural Muslim communities and exposing oppressive discourses. The study suggests appropriating epistemological paradigms to reveal subversive gendered discourses in the Muslim society.

\section{References}

Ahmad, S. (2010). Multiple Locations and Competing Narratives (pp. 1-11) in A. Khan \& S. Ahmad (Eds.) Pakistani Women: Multiple Locations and Competing Narratives. Karachi: Oxford University Press.

Althusser, L. (1971). Lenin and Philosophy and Other Essay. London: New Left Books.

Alwan, D. H. (2012). Programming of Fear: The Cultural Context of Islam and Muslim Characters. East Eisenhower Parkway: ProQuest LLC.

Barmak, S. (2003). Osama. Afganistan: Barmak Film

Bhanbhro, S. et al. (2013). Karo Kari - The Murder of Honour in Sindh Pakistan: An Ethnographic Study. International Journal of Asian Social Science, 3(7), 1467-1484.

Benali, A. (2015, January 13). From teenage angst to jihad: The Anger of Europe's Young Marginalized Muslims. The New York Times. http://www.nytimes.com/2015/01/ 14/opinion/the-anger-of-europes-young-marginalized-muslims.html (Retrieved in November 27, 2016)

Butler, J. (2010). Gender Trouble: Feminism and the Subversion of Identity. New York: Routledge.

Caputi, M. (2013). Feminism and Power: The Need for Critical Theory. Lanham: Lexington Books. 
Clement, C. \& Kristeva, J. (2001). The Feminine and the Sacred. New York: Columbia University Press.

De Beauvoir, S. (1949). The Second Sex. New York: Knopf Doubleday Publishing Group.

Derrida, J. (1976). Of Grammatology. Baltimore: John Hopkins University Press.

Fairclough, N. (2010). Discourse and Social Change. Cambridge: Polity Press.

(1998). Critical Discourse Analysis: The Critical Study of Language. England: Longman.

Foucault, M. (1976). The History of Sexuality. Paris: Editions Gallimard.

(1972). The Archeology of Knowledge. London: Tavistock.

Habermas, J. (1987). The Philosophical Discourse of Modernity: Twelve Lectures. Cambridge: Polity Press.

Haeri, S. (2010). Fascination with 'difference': Democratizing Anthropology, Conducting Fieldwork among Equals (pp. 278-287) in A. Khan \& S. Ahmad (Eds.) Pakistani women: Multiple Locations and Competing Narratives. Karachi: Oxford University Press.

Howarth, D. (2000). Concepts in the Social Sciences: Discourse. Buckingham, Philadelphia: Open University Press.

Gramsci, A. (1971). Prison Notebooks. London: Lowrence and Wishart.

Jamal, A. (2010). Gender, Citizenship, and the Nation-State in Pakistan: Wilful Daughters of Free Citizens (pp. 120-139) in A. Khan \& S. Ahmad (Eds.) Pakistani Women: Multiple Locations and Competing Narratives. Karachi: Oxford University Press.

Kasturi, L. (1996). Development, Patriarchy and Politics: Indian Women in the Political Process, 1947-1992 (pp. 99-144) in V. M. Moghadam (Ed.) Patriarchy and Economic Development: Women's Positions at the End of Twentieth Century. New York: Clarendon Press. 
Khan, R. (May 26, 2016). Light Beating Wife Permissible, Says CII's Proposed Women Protection Bill. Dawn. http://www.dawn.com/news/1260803 (Retrieved in September 13, 2016).

Khoja-Moolji, S. (2015). Suturing Together Girls and Education: An Investigation into the Social (re)Production of Girls' Education as a Hegemonic Ideology. Diaspora, Indigenous, and Minority Education, 9, 87-107.

Laclau, E. (2007). Discourse (pp. 541-547) in R. E. Goodin, P. Pettit \& T. Pogge (Eds.) A Companion to Contemporary Political Philosophy. Oxford: Blackwell Publishing Ltd.

Lakoff, R. (1973). Language and Woman's Place. Language in society, 2(01), 45-79.

Lari, M.Z. (2011). Honour Killings in Pakistan and Compliance of Law. Islamabad: Aurat Publication and Information Service Foundation.

Lazar, M. M. \& Kramarae, C. (2011). Gender and Power in Discourse (pp. 217-240) in T. A. van Dijk (Ed.) Discourse Studies: A Multidisciplinary Introduction. London: Sage Publications Ltd.

Levi-Strauss, C. (1977). Structural Anthropology. Harmondsworth: Penguin.

Mansoor, S. (2007). Khuda Kay Liye. Pakistan: Shoman Production.

McKee, R. (1997). Story. NewYork: Harper Collins.

Millett, K. (1970). Sexual Politics. London: Rupert Hart-Davis Ltd.

Mills, S. (2005). Critical Thinkers. London and New York: Routledge

Patel, S. \& Gadit, A. M. (2008). Karo-kari: A form of Honour Killing in Pakistan. Transcultural Psychiatry, vol.45:4, pp.683-694.

Pratt, J. (June 28, 2016). Women are Key to Development. The Express Tribune. https:/tribune.com.pk/story/1131385/women-key-development/ (Retrieved in September 13, 2016)

Riazul-Haq. (June 29, 2016). Senate Panel Questions Legal Standing of CII. The Express Tribune. https://tribune.com.pk/story/1132632/anti-women-stance-senate-panelquestions-legal-standing-cii// (Retrieved on September 13, 2016) 
Rouse, S. (2004). Gender, Nation, State in Pakistan: Shifting Body Politics. New Delhi: Women Unlimited.

Russell, B. (1988). My Philosophical Development. Sydney: Unwin Hyman Ltd.

Salami, A. \& Ghajarieh, A. (2016). The Gender Discourse of 'Equal Opportunities for Men and Women' in Iranian EFL Textbooks. Gender in Management: An International Journal, vol.31:2, pp.114-133.

Said, E.W. (1978). Orientalism. New York: Vintage Book.

Saigol, R. (2011). Women's Empowerment in Pakistan: A Scoping study. Islamabad: Aurat Publication and Information Services Foundation.

Saussure, F. (1974). Course in General Linguistics. London: Fontana.

Semmerling, T. J. (2006). "Evils" Arabs in American popular film: Orientalist fear. Texas: University of Texas Press.

Shaheen, J. (2001). Reel Bad Arabs: How Hollywood Vilifies a People. New York: Olive Branch Press.

Shaheen, J. (2000). Hollywood's Muslim Arabs. The Muslim World, vol.90, pp.22-38.

Siddiqui, S. (2014). Language, Gender, and Power: The Politics of Representation and Hegemony in South Asia. Karachi: Oxford University Press.

Spivak, G. (1996). Feminism and critical theory (pp. 63-84) in D. Landry \& G. MacLean (Eds.), The Spivak Reader. New York: Routlege.

Strauss, S. \& Feiz, P. (2014). Discourse Analysis: Putting Our Worlds into Words. New York: Routledge.

Sunderland, J. (2004). Gendered discourses. Basingstoke: Palgrave Macmillan.

Thorne, B. \& Henley, N. (1975). Language and Sex: Difference and Dominance. Rowley: Newbury House Publishers.

Tyson, L. (2015). Critical Theory Today: A User Friendly Guide (Third edition). New York: Routledge. 
(2009). Critical Theory Today: A User Friendly Guide (Second edition). New York: Routledge.

(2006). Critical Theory Today: A User Friendly Guide (First edition). New York: Routledge.

Van Dijk, T.A. (Ed.). (2011). Discourse Studies: A Multidisciplinary Introduction. London: Sage.

Wilkins, K.G. (2009). Home/land/security: What We Learn About Arabs Communities from Action Film. Lanham: Lexington Books.

Woolf, V. (1929). A Room of One's Own. England: Hogarth Press.

Wodak, R. (Ed.). (1997). Gender and Discourse. London: Sage.

Yanow, D. (2014). Thinking Interpretively: Philosophical Presuppositions and Human Sciences (pp. 5-26) in D. Yanow \& S. Peregrine (Eds.) Interpretation and Method: Empirical Research Methods and the Interpretive Turn, (Second edition). New York: M.E. Sharpe.

Dr. Muhammad Shaban Rafi is Chairman in the Department of English Language \& Literature, University of Management and Technology, Lahore, Pakistan. 